\title{
Poetry Onstage: The refrein in Rederijker Drama
}

\author{
Dirk Coigneau
}

\section{1 Introduction}

This contribution deals with the use of the refrein in the dramatic production of the chambers of rhetoric. In the sixteenth century, Dutch-spoken theatre was dominated by the officially recognized and legalized chambers of rhetoric that had sprung up, from the middle of the fifteenth century onwards, in almost every town of Flanders, Brabant, Zeeland and Holland. ${ }^{1}$ Next to drama, which was often staged on festive occasions and in theatrical contests, the chambers' activities focused on the production of lyric works. The poetic form most practised and most highly regarded by the ghesellen vander retoriken ('companions of rhetoric'), retorikers, ret(o)risienen or rederijkers, as the chambers' members were called, was the ref(e)rein, the rederijker variant of the French ballade. ${ }^{2}$ In accordance with most contributions in English on the rederijkers, the poets will be referred to in the following as 'rhetoricians'. The word 'rederijker' will be used here as an adjective, and the plural of 'refrein' (in Dutch refreinen) will be anglicized into 'refreins'.

Like its French prototype, the refrein consists of stanzas ending in the same line (in the French ballade the refrain); the last stanza (in the ballade the envoi) begins with a reference to the prince, that is, the honorary chairman of a chamber or rederijker meeting. The merely nominal reference to the prince often engendered dedications that were more aligned to the specific contents of the poem, whereby prince, for instance, could be turned into princesse. Compared with the French ballade, the Dutch refrein showed a tendency to get longer. In the course of the sixteenth century, the prince-stanza, which was originally shorter than the preceding ones, adopted the size of the latter. Together with its envoi, the French ballade had four stanzas. This number remained the norm in

1 On the history and activities of the chambers of rhetoric in the Southern and Northern Netherlands, see: Van der Heijden and Van Boheemen (1999), Van Boheemen and Van der Heijden (1999), Van Bruaene (2008), Van Dixhoorn (2008 \& 2009). A list of 'Rederijkerskamers 1400-1650', with literature, can be consulted via www.dbnl.nl (organisaties).

2 On refrein and refrein-contests, see: Van Elslander (1953), Coigneau (1980-1983) vol. 1. 9-31, 193-212; Coigneau (1995) 123-129, and Coigneau (200o \& 2003). 
the refrein throughout the rederijker period, but outside of poetical contests, refreins could eventually expand up to ten or even more stanzas. Generally, the stanzas of a refrein comprised more and longer lines $(13,15$ or more of about 9 to 13 syllables) than those of the ballade (8 to 11 lines of 7 or 10 syllables). The recitation of an average refrein took about three and a half minutes, which can be compared with the length of a modern pop song. As far as their subject matter is concerned, refreins were subdivided into three main categories: didactic, moralizing or religious poems (in'tvroed or wijs), amorous complaints and praises or general views on love (in 't amoureus) and comic matter, spicy anecdotes or satire on human Folly (in 't zot).

The writing and reciting of refreins can be described as the main business of the chambers of rhetoric. In their statutes the chambers stipulated when and how refrein contests had to be organized among their members. Next to these regular internal exercises, chambers could also compete with each other in festive gatherings. In all these competitions, refreins were required to answer a certain question or to be built on a given regel or stok, the rederijker term for the recurring line that had given its original French name (refrain) to the poem as a whole. Apart from these competitions, the free creation of refreins, not aiming at a particular reward, was of course also appreciated. Lovers of the genre collected and copied refreins in manuscripts. Some collections, many containing the poems written for interurban contests, appeared in print. About 2,300 refreins have come down to us in these fifteenth- and sixteenth-century collections.

Next to refreins featuring as independent texts in collections, refreins appeared also as stylized passages in rederijker drama. ${ }^{3}$ Looking into these, three important features may strike the researcher's eye. The first concerns the form of refreins in the earliest, fifteenth-century plays versus those in later, sixteenthcentury drama. Secondly, there is a complete absence of refreins in comic drama, in contrast to their appearance in serious allegorical plays and dramatized stories (the so-called spelen van sinne). Finally, there are, within this last group, the plays with refreins as distinct from those without. In this contribution I will try to throw some light on these diverging categories.

3 On refreins in rederijker drama, next to other poetical forms: Coigneau (1994). Refreins have also been incorporated, some taken from collections, in printed prose-romances. On this: Debaene (1951) 347-351; Vinck (1976-1977) 27-29, 35-45, and Resoort (1988) 152-179. 
The authors of rederijker plays who can be dated with certainty to the fifteenth century seem to have hesitated to introduce fully-fledged refreins in their texts. Instead of poems consisting of four stanzas, the last of which is indicated by means of (some form of) the word prince, we find here poems of only three stanzas, without a prince stanza (Elckerlijc, Quiconque vult salvus esse, Sanct Jooris and Die geboorte van Vrou Margriete). ${ }^{5}$ In later plays, refreins with less than four stanzas and without prince-indications are rather exceptional. The stanzas of the refreins in the fifteenth-century plays also tend to be shorter than those of regular lyrical refreins. In Anthonis de Roovere's play Quiconque vult salvus esse, for instance, they have only six lines, whereas the two shortest refreins in this poet's lyric oeuvre consist of three stanzas of seven lines plus a fourth stanza of, respectively, six and eight lines. ${ }^{6}$

In fifteenth-century plays the number of the refrein stanzas is clearly influenced more by the dramatic context and content than by a given format. In Quiconque vult salvus esse, Sanct Jooris and Colijn Cailleu's Die geboorte van Vrou Margriete, each of the three stanzas is alternately spoken by one of the three most relevant characters, the recurring line highlighting their unanimity of feelings about the play's final solution or activity. In De Roovere's play these are the three characters who defended Christian lore in a debate against Jews and Muslims. In the refrain they all three honour Christ's suffering and death,

4 The plays will be referred to by the short titles used in Hummelen (1968): see the Appendix.

5 See the Appendix, numbers 127, 1, 16 and 8. In Die geboorte van Vrou Margriete the refrein is followed by a rondel in which the mother and child are taken leave of (1. 474-481/2): in this the mother is addressed three times as 'moedere der edelhede' and once (in line 478) as 'priencersse des huys vol vreden'. On this refrein also: Pikhaus (1989) vol. 2. 365-366.

6 Mak (1955) 339 and 392. On the 62 refreins in Mak's edition (a few of which, containing not merely the same rhyme scheme, but (as in the French ballade) also identical rhyme sounds in all stanzas, are called 'balade'), there are 17 refreins with stanzas of 15 , twelve with stanzas of 13, and twelve with stanzas of ten lines. There are (only) seven refreins with stanzas of eight lines, two with stanzas of nine, two with stanzas of eleven, four with stanzas of twelve, two with stanzas of 14, and two with stanzas of 17 lines. In Elckerlijc's refrein the first stanza has nine lines, against ten lines in the second and third stanzas. In Sanct Jooris the stanzas have eight, in Die geboorte van Vrou Margriete twelve lines. In his Const van Rhetoriken, a manual on Dutch versification, completed in 1548 and published in 1555, Matthijs de Castelein reserves the word 'balade(n)' for poems of one or more stanzas of seven to nine lines (see De Castelein (1555) 53, stanza 158, and the examples on 66-116). De Castelein calls poems with these short stanzas and a recurring last line, 'Balade, Referein' or 'Balade(n) Referein wijs', although in his own Flanders they are also indiscriminately referred to as 'Refereinen' (De Castelein (1555) 95, 114 (stanza 201), and 116 (stanza 202)). 
beseeching His help in their last hours. In Cailleu's play each stanza is successively recited by one of the representatives of the three estates, namely nobility, the clergy and the cities, in a scene modelled on the three wise men's offering of gold, incense and myrrh. In Sanct Jooris, as in De Roovere's play, the refrein is a prayer: the first stanza, spoken by Saint George, addresses God the Father, while the king praises Christ in the second and the king's daughter, a virgin rescued by Saint George from being sacrificed to a dragon, glorifies the Virgin Mary in the third. In Elckerlijc the same triumvirate is addressed in a refrein, all three stanzas of which are spoken by the protagonist Elckerlijc (Everyman).

The omission of a fourth or last stanza with its reference to the prince may have been seen as a way to dissociate the poem's form from contexts involving recitations of separate refreins in rederijker gatherings. Freed from its original 'practical' context, the genre could be better integrated into the play's dynamics. Especially in Elckerlijc, where the refrein is positioned in the middle of the play, a closing prince-stanza would have caused a dysfunctional break. The refrein is the first piece of long speech in the play, and the first prayer. Having looked for someone to accompany him on his inevitable pilgrimage to death, Elckerlijc has found only his Virtue willing, but unfortunately also too sick, to go with him. His Virtue can only be cured, Elckerlijc learns, when he seeks the help of Confession. When he does so, Confession gives him a birch, called Penitence, with which he has to castigate himself. Elckerlijc's chastisement is the central moment and turning point in the play. Before Elckerlijc starts this impressive act, he speaks a refrein in which he prays to God, Jesus and Mary for grace and support. Speaking in terms of narrative economy, the refrein is an unnecessary retardation in the unfolding of the plot. In terms of dramatic effect, however, the prayer intensifies the earnestness and 'sacredness' of the ensuing act. A closing prince-stanza might have spoilt the effect by dissociating prayer and chastisement. It is worth noting that a few examples of this functionally motivated omission of the closing prince-stanza can also be found in later plays; these are always refreins that are part of a broader dialogue or scene. ${ }^{7}$

In De sacramente vander Nyeuwervaert, dating also from the fifteenth century, the refrein consists of four stanzas. ${ }^{8}$ The last stanza, however, is not shorter than the preceding ones, as one might have expected in an early refrein. In addi-

7 We find a refrein with only two stanzas in Die propheet Jonas (Appendix: 43), refreins with three stanzas and no prince in De bekeeringe Pauli and Die propheet Jonas (Appendix: 24 and 42); and with a prince-indication in Die heijlige kercke tegen heresije and De Ontrouwe Rentmeester (Appendix: 62 and 92). In Het lichamelijcke huis and De Desolate Mensch the fourstanza refreins take the form of a dialogue, without prince-indications (Appendix: 57-61).

8 See Appendix: 101. The stanzas have eight lines each. 
tion, the number of four stanzas can again be explained by the three characters involved in the scene. The main character is Heer Wouter, a knight who goes to venerate the miraculous Holy Sacrament in the church of Nyeuwervaert, a small place near the Brabantine city of Breda. Accompanied by the parish priest and the bailiff, Heer Wouter enters the church. On seeing the Holy Sacrament, Heer Wouter recites the first stanza of the hymnal refrein, the priest and bailiff following his example with, respectively, the second and third stanza. Since the veneration was the personal ambition of Heer Wouter, the author has given him his due by letting him speak a second stanza, the fourth and last one of the refrein. In this final stanza, Christ is called 'prince above all princes', not, as one would expect in a 'regular' refrein, in the first, but in the penultimate line of the stanza. Here the prince-reference clearly indicates the closing of the poem, functionally marking it out as a prayer distinct from the ensuing dialogue.

In the fifteenth century, we may conclude, the functional integration of the refrein in dramatic action tended to reduce the form to its rhythmic essentials: the recurrence of the last refrain line (stok) in a number of stanzas of equal length. ${ }^{9}$ Because of its repeated stok and ample stanzas, the use of the refrein in drama necessarily goes together with moments of 'low velocity' 10 that take time for actual reflection and passive contemplation. In this respect the refrein clearly deviates from the rondel, another form with recurrent lines that is also used in rederijker drama. In comparison with the rondel, which can be inserted at moments of low as well as of high dramatic velocity, the range of situations in which the refrein can be used is in fact far more restricted; this makes it the more specific of the two genres.

Unlike refreins, rondels are closed and circular poems, consisting always of eight or nine lines only. The rapid repetition of the first line as the fourth and seventh, and the recurrence of the second line as the final or last but one (the rhyme scheme being: $\mathrm{ABaAabAB}[\mathrm{b}])$, may produce a hectic, accelerating effect. Rondels were in fact often used to open a scene with the hurrying-up of one character by another to enter the stage. Often the rondel's repetitive lines are utilized to provide the audience with information at an opening in medias res. Recurrence within a circular frame does not always rouse a sense of urgency, however. Connected with ritualized activities, the rondel may also evoke a kind

The idea that a refrein is defined by the presence of a prince-stanza and not by the recurring stok (see Hüsken (1994) $5^{0-52,56)}$ is based on a misinterpretation of De Castelein (1555) 53, stanza 159 (see also 54, stanza 16o, and 116, stanza 202).

10 On the term '(moments of high and low) velocity' as a 'spatial' variable within the sequence of theatrical tension, constituting dramatic action, see Beckerman (1970) 49-50. 
of 'filmic' still. This is, for instance, the case with rondels spoken by characters giving a toast, or those replying to one. Finally, rondels may express emotions, for instance in characters bidding each other good-bye, or can give affective emphasis to praises or supplications. ${ }^{11}$ The last two emotional responses also suit the refrein. If one compares the two forms in this field, the refrein is certainly superior in its capacity to combine the pathetic recurrence of lines with steadiness of exposition and contemplation. It is precisely this evocation of emotion together with broader reflection or argumentation that determines the refrein's specific position vis-à-vis the rondel.

Looking again into our fifteenth-century texts, it is clear that the authors reserved the refrein for the most solemn moment in their plays. Each of these moments presents an activity in which the expression of a 'final' emotional response is combined with reflection and moralization. In Cailleu's Die geboorte van Vrou Margriete, the recitation of the refrein accompanies the ultimate offering of a golden apple, a rose and leaves to figures representing the newly born princess Margaret (born on the 1oth of January, 1480) and her mother (Mary of Burgundy). The refrein humbly beseeches them to accept the offerings, explaining that the presents' moral qualities signify princely virtues. ${ }^{12}$ In Elckerlijc, Sanct Jooris, Quiconque and De sacramente vander Nyeuwervaert, the refreins are religious prayers. In Elckerlijc, this prayer elucidates the protagonist's submission to ecclesiastical Confession and Penance in terms of hope and faith in God's mercy and Mary's advocacy. In Sanct Jooris, De sacramente and Quiconque, the laudatory refreins celebrate the happy outcome of the action or discussion. In the last two plays mentioned, the prayer responds more specifically to the exhibition of a so-called toog (literally: 'the showing of something'). This is a presentation of a picture or tableau vivant in a special compartment of the stage-construction, which, like a window, was usually situated on a higher level than the proscenium and could be opened and closed with curtains. ${ }^{13}$ In De sacramente the toog must have been a monstrance, representing the Nyeuwervaert miraculous Holy Sacrament, in Quiconque it was a crucifix or some other visualization of Jesus on the cross.

In contrast to our early examples, almost all refreins in sixteenth-century plays fully conform to the classic model of four stanzas (with an average length of about 13 lines each), the last of which is entitled prince or addresses somebody

11 On the use of the rondel in rederijker drama, see: Hummelen (1958) 74-81; Pikhaus (1989) vol. 2. 390-414, and Coigneau (1994) 26-29.

12 On Cailleu's play and its political meaning: Mareel (2010) 143, 156-165, 254.

13 On the toog: Hummelen (1992) 193-222. 
as prince. Only eight of the 129 sixteenth-century refreins which we studied consist of more than four stanzas. ${ }^{14}$ In five of these, the exceptional number of five or six stanzas is clearly linked to the number of actors (five or six), each of whom participates in the performance of the refrein by reciting one stanza. ${ }^{15}$ Two refreins break out of this format, however. In Wercken der bermherticheyd $I V$, a six-stanza refrein occupies a central position in the argumentation on the merciful work of clothing the naked. Standing in front of a toog showing the Crucified, (only) two instructing characters speak three stanzas each in alternation, criticizing vain, worldly persons and urging them to contemplate the image of the naked Christ. As the six stanzas are each twenty lines long, this exceptional refrein is also the longest piece in our corpus. ${ }^{16}$ In Robert Lawet's De helighe sacramente five stanzas are divided between three characters. ${ }^{17}$

Conversely, on a dramaturgical level the fixed number of four stanzas to a refrein doesn't seem to have generally led to the introduction of four participants. ${ }^{18}$ Only 14 of our 129 refreins were recited by four different characters in turn. One of these is an interesting case to compare with Cailleu's Die geboorte van Vrou Margriete: the anonymous Josep ende Maria, a Christmas play preserved in a vast collection of pieces started by the Haarlem chamber 'Trou Moet Blijcken'. In this play the first three stanzas of a refrein are respectively spoken by Baltasar, Melchior and Jasper, praying to the Christ Child and moralizing in the same way as the three estates did in the play of Cailleu. The refrein in Josep ende Maria has one more stanza, however, in which it is Mary who speaks, reinforcing the three wise men's wish that her child may accept their offerings. ${ }^{19}$

14 The refrein in Sincte Paulus Bekeringe (Appendix: 35) is not counted in. This speech of Paul, consisting of five stanzas, may be considered as an amplification of the more original refrein of four stanzas in De bekeeringe Pauli (Appendix: 25).

15 There are five stanzas and five different characters in Lauris Jansz' Lieft boven al (see Appendix: 54); the fifth stanza is spoken by Lijefde, responding to the preceding stanzas, the fourth of which is the prince-stanza: the same goes also for the refrein in the prologue of De Ghichtige Mensche, Appendix: 53); there are six stanzas with six characters in Christiaen Fastraets' Sint Trudo (Appendix: 99), Robert Lawet's Het vader onse (Appendix: 29), Wercken der bermherticheyd VI (Appendix: 123), and Wercken der bermherticheyd VII (Appendix: 126).

16 Appendix: 120.

17 Appendix: 28.

18 Except probably for the four (instead of the usual two) instructing characters in the Wercken der bermherticheyd: in four plays the same four characters speak the final refreins (Appendix: 117, 118, 119, and 121); in the sixth and seventh play these speakers are joined by two other characters (Appendix: 123 and 126).

Appendix: 56 . 
Of the 129 refreins, a majority of 73 refreins are spoken by one character, in some cases creating a relatively long, if not the longest speech in the play. Next to 20 refreins divided between two characters, each receiving two stanzas, there are also 15 four-stanza-refreins shared between three performers. Most of these form part of a final scene in which the triumvirate of participating characters consists of a representative of Mankind and his two moral or spiritual supporters. After the three first stanzas have each been recited by a different character, the two most practised patterns for completing the refrein are either a) a cyclical one (as described above in De sacramente vander Nyeuwervaert), in which the main or central figure who has recited the first stanza also recites the last; or b) by subdividing the prince stanza into three shorter parts, each to be spoken by one of the three characters.

Unlike our fifteenth-century examples, some sixteenth-century plays exhibit more than one refrein. Nevertheless, a majority of plays has only one refrein and in those with more than one, the number is restricted to two or three refreins, except for Cristenkercke, which has four. ${ }^{20}$

As in Sanct Jooris, Die geboorte and Quiconque, many sixteenth-century plays use refreins to form a final dramatic high point (out of 129 refreins we count 48 in final position). All of these refreins are prayers or laudatory contemplations and moral exhortations, which may be framed as prayers too by means of initial lines, the prince-stanza and/or the stok. Often these are the only prayers in the play, many of them responding, as in De Roovere's Quiconque, to a toog that displays Christ crucified or another biblical or religious subject. ${ }^{21}$ Within the overall structure of the plays, refreins in closing scenes consolidate the positive outcome in a 'festive' way. This celebration by means of an artistic construction of speeches apparently did not hamper its persuasiveness. On the contrary: the spectator's pleasure at recognising that the closing speech(es) are a refrein goes well with the 'happy end' which is the main character's reward. In addition, since the refrein was an approved poetic form for separate ('real') prayers in breviaries and in devotional practices, ${ }^{22}$ the stylized praying onstage may have made for a higher degree of audience intimacy.

20 Appendix: $20-23$. The parallel play De Heijlige Kerck (Appendix: $48^{-50}$ ) can do it without 22.

21 So in (Appendix): 5, 7, 15, 19, 28, 29, 31, 34, 55, 75, 76, 98, 106, 107, 110, 111, 117, 118, 119, 120, 121 and 123 .

22 Our oldest refreins are preserved in collections of prayers and breviaries: see Oosterman (1995) vol. 1, 117-209, and vol. 2, nrs. 4, 25, 26, 49, 152, 153, 235, 290, 305, 335, and 345. 
As in Elckerlijc, refreins could also be utilized in sixteenth-century plays in order to introduce or actuate a decisive step or turn in the action. Although not all of these refreins appear somewhere 'in the middle' of the play-some, producing a final argument, are rather to be found close to the end-we will call them 'central', which may be conceived, if necessary, in a slightly metaphorical way (out of 129 refreins we count 42 'central' ones). And as in Elckerlijc, these refreins may either be prayers or more specific supplications that result in the state of affairs hoped for. Except for one refrein in which Pyramus begs Venus for an opportunity to speak with Thisbe, and another in which Hijarbas begs for Jupiter's interference, (in Pyramus ende Thisbe and Cornelis van Ghistele's Eneas en Dido respectively), ${ }^{23}$ all the prayers are of a Christian tenor. The turn in the action can also be brought about from above: particularly impressive and effective, in fact, are the refreins spoken by figures of higher authority, representatives of God's love, or the figure of Christ himself, who sometimes appears in a toog. In these refreins men are reprimanded and threatened for their worldliness and/or summoned to put their trust in the offer of God's mercy. ${ }^{24}$ In De Evangelische Leeraer, appropriate to his will, Christ recites his refrein while standing in an open door. Most remarkable, however, is the refrein in Robert Lawet's De Verlooren Zoone. The poem, consisting of four stanzas of fifteen lines each, with in the first stanza fifteen times the anaphora 'Compt alle [tot my]', in the second and third stanzas respectively thirteen times 'Ick ben' and 'Ick hebbe' and in the last one nine times 'Ick ben' or 'hebbe', is spoken by Christ while hanging on the cross. Subscriptions tell us that the play was finished on the 21st of September ${ }_{15} 83$ in Bruges, which was at that time under Calvinist rule. How then, one may wonder, did spectators receive this combination of theological 'truth' with the 'historical' impossibility of Christ, reciting a poem of 60 lines from out of the cross? Here the refrein seems to show one of its 'magical' functions in drama, creating an aesthetic niche, powerful enough to warrant a temporary suspension of biblical criticism and disbelief. At least on the stage the use of refreins by figures of higher authority does not fail to lead their addressees to new insights and conversion. The play's central turning point, however, may also be located within the refrein itself. In Abrahams offerhande, for instance, Abraham's decision to obey God's order to sacrifice his son is taken in the sole refrein in the play, and in Lauris Jansz's Meestal die om Paijs roepen King Phillips' decision to stop the war with France for the benefit of his subjects is taken in the course of a central refrein. ${ }^{25}$ Finally, the central

23 Appendix: 128 and 13.

24 See Appendix: 21, 23, 30, 49, 50, 52, 114, 131.

25 See Appendix: 32 and 67 . 
refrein may also mark out the beginning of a new phase in the main character's development. In Vreese des Heeren en Wijsheijt, for instance, the protagonist enthusiastically recites a love refrein, borrowing most of its images from the Song of Solomon, after having spoken his beloved 'Justification' through the window of her chamber, which is called 'God's Word.' ${ }^{26}$

There is one more recurring type of refrein found in central scenes that is relatively distinct from the above. In these, characters express their worldly preoccupations in a rather provocative way. Their position seems powerful, but, in a moral sense, their situation is highly precarious. Most of these refreins are meant to be spoken by actors taking part in a rich banquet. The recitation of the refrein, usually in 't amoureus mode, may be interrupted by musical performances, singing or rondels, arranged in broadly balanced scenes. ${ }^{27}$ These splendid banquet scenes represent worldly and reprehensible life in the same way as the more 'vulgar' tavern and brothel scenes do in other plays. Viewing both types together, ${ }^{28}$ however, the banquet scenes illustrate in a striking way the higher status of the refrein, even in a secular context: whereas the refrein forms a central and substantial part of the exhibition of luxurious and betterclass amusement in banquet scenes, tavern and brothel scenes have songs and rondels, but do not contain refreins.

No precedent is found in our fifteenth-century texts for the initial position some refreins take in sixteenth-century plays (out of 129 refreins we count 39 initial ones). In fact, plays with one refrein only, spoken in the expositional part of the play, are scarcely present in our sixteenth-century corpus. ${ }^{29} \mathrm{~A}$ fair example is the complaint of the sick protagonist in Naaman, consisting of (only) three stanzas, each ending in the purely emotional line 'Och och ende och ende meer dan och'. Most common, in contrast, are plays that couple initial refreins with final ones. ${ }^{30}$ Especially when both refreins are spoken by the same main character (who sometimes shares the final refrein with moral instructors), the initial and a final refrein frame the action in a way that clearly profiles the dramatic contrast between the beginning - which is not necessarily the first scene-and the end. A good example is De bekeeringe Pauli, in which Saul's first speech starts with a refrein, a false and fictitious prayer that promises

\footnotetext{
26 Appendix: 100.

27 Appendix: 9, 10, 39, 94. In the short satirical factie of Berchem (see Appendix: 108) the refrein is combined with the conventional final song in a culminating wedding-party.

28 On tavern and banquet scenes: Hummelen (1958) 142-148.

29 Appendix: 4, 11, 12 (part of the prologue), 53, 78, 89, 103.

30 Appendix: $2-3,24-25,37-38,62-63,69-70,73-74,75-76,80-81,82-83,90-91,104-106$, 109-110, 122-123.
} 
God to persecute the Christians with great zeal; his last speech, the second refrein, is a sermon that preaches Christ as the way, the truth and the life. ${ }^{31}$ Most other initial refreins are an exposition of the protagonist's problematic situation, often in an emotional soliloquy that expresses his or her doubts and sadness or (fear of) total despair. The latter is, for instance, found in Noordwijk: spel van sinne in Rotterdam 1567. 'Fall down you mountains and cover me' is the recurring line at the end of each stanza, inspired as it is by Hosea 10:8 or Revelation 6:16. Like Job, the despairing protagonist curses the hour of his birth, but he also calls upon all the devils to take him away. Refreins like these are purely 'dramatic': they cannot function separately in refrein-collections, isolated from the play's moral instruction and comfort given in the subsequent action. ${ }^{32}$

In plays with two refreins, it is also possible for initial and central refreins to be combined, ${ }^{33}$ or a central refrein may also be followed by a final one. ${ }^{34}$ The first combination profiles the problematic first half of the play, the second one the second, remedial part. In tReyne Maecxsele, for instance, the central refrein (on the stok: 'Both heaven and earth are incensed by me'), spoken by a (female) representation of Mankind, captured in limbo, is as desperate as her first lament (on the stok: 'Never I will be redeemed'), but the second poem provokes the appearance of the character 'Comforting Support' and Christ, bearing his cross. In the central refrein in Tspel van Judith on the other hand, the four stanzas of which are alternately spoken (on the stok: 'Being with you rejoices my heart') by Holofernes and Judith in a banquet scene, both participants celebrate each other's lovely company. Judith's real joy applies of course to the successful approach to her goal. After her beheading of Holofernes, her joy, combined with gratitude to God's faithfulness, is expressed, unveiled and unhampered now, in a final refrein, spoken all by herself (on the stok: 'Lord, all those who put their trust in You must rejoice').

Contrary to what one might expect, there are not many plays showing a combination of the three positions distinguished here. ${ }^{35}$ In plays with three refreins, the expositional phase may rather be broadened and deepened by more than one character, each of them commenting on the same problem in his or her own initial refrein. ${ }^{36}$ The same goes even for central refreins. In

\footnotetext{
31 Appendix: 24-25.

32 Coigneau (2005) 250.

33 Appendix: 26-27, 51-52, 6o-61, 86-87, 113-114.

34 Appendix: 84-85, 94-95.

35 In fact only Appendix: 66-68.

36 Appendix: 17-19, 57-59, 129-130, 132-134.
} 
Verlaten Kennisse, for instance, a banquet scene refrein is followed by a reprimanding refrein, and in Die propheet Jonas the salvation of the town of Nineveh is achieved by an accumulation of three prayer refreins, spoken by different characters in succession. ${ }^{37}$

From the foregoing survey we can conclude that rhetoricians used refreins in serious drama in order to stylize and highlight the most powerful moments in the protagonist's story, the dramatic power being imparted by the main character's own emotional and devotional attitude and by the impact of assisting authorities. In talking about the protagonist's story, I mean here the main character's overall 'moral' development. In the dramatic structure of the rederijker morality play, a very important role was played by the so-called sinnekens. These negative allegorical figures, almost always appearing in twos, are diabolical workers of mischief, nervously plotting and trying to lead the main characters astray. Their emotional reactions in scenes full of 'infernal mirth and demonic mockery'38 may have a powerful dramatic effect on the spectators, too, and their (temporary) impact on the protagonist can also be very strong. Still, rhetoricians never let them speak a refrein. In their hectic dialogues, the sinnekens often produce rondels, but never have time or space for the more contemplative refrein. Rhetoricians clearly reserved refreins for more earnest, solemn or graceful scenes.

In most moralities the sinnekens' impact is ultimately overcome; this is not however the case in the amorous plays dramatising love-stories such as those of Piramus and Thisbe, Dido and Eneas or the 'true' Dutch history of Katherina Sheermertens and Dierick den Hollander. In these plays, the sinnekens succeed in stirring up the protagonists' desires until their immoderate passions drive them to their fatal end. The dramatisation of the above-mentioned love-stories produced a few initial and central refreins. ${ }^{39}$ More striking however is the complete absence of final refreins in all rederijker amorous drama. Although a vast quantity of autonomous refreins, preserved in (mainly printed) collections, consists of desperate amorous lamentations, in drama rhetoricians clearly didn't want to stylize and highlight their tragic endings in the same way as they 'celebrated' their happy ones.

37 Appendix: 39-40, 42-44; also 20-23 and 48-5o.

38 Quote from Hummelen (1984) 17. On the sinnekens: Hummelen (1958).

39 Appendix: 14, 128, 129, 130; also 96. 
All refreins in rederijker drama, including the banquet refreins representing pleasant though immoral conduct, were intended to be taken seriously. None of the 134 cases we have considered really aimed at a comic effect. Although some kinds of refreins in ' $t z o t$, in particular monologues by henpecked husbands or drinking companions, ${ }^{40}$ might function very well in comic drama, refreins do not appear in the rederijker farce. Taking their main characters' position as the starting-point, a tripartite structure can also be discerned in farces. The initial position could be reversed or consolidated by a central twist in the action, usually involving a cunning device, a misapprehension or a surprise (coup de theâtre). ${ }^{41}$ In some farces, the initial, expositional segment or the dynamic central one is profiled, or even constituted, by means of lyrics, more particularly by the singing of a song. ${ }^{42}$ In Lijsgen en Jan Lichthart and De sotslach, for instance, the songs are to be found in the dynamic segment, furnishing thereby a parallel with central refreins in morality plays. ${ }^{43}$ In Lijsgen and Jan Lichthart, the song is sung by three women, reprimanding one of their husbands for his excessive drinking. The singing, which provides a rhythmic accompaniment as the soak is tossed in a blanket, turns out to be a very effective cure. His terrible experience is explained as a lesson given to him by 'Our Lord', and the man promises his wife never to get drunk again. In De sotslach, a peasant is led by a singing jester on an egg dance. Misunderstanding the ironic meaning of the jester's song, the peasant persists in his ambition to gain the fool's cap as the real ass's wreath of honour.

These songs are the only ones in our farces consisting of stanzas with an identical last line. In De sotslach the last stanza even has a prince reference. Still, the spectator will have recognized both poems clearly as songs and not as refreins: because of their delivery by singing, of course, but also because of their lines and stanzas, which are too short for a refrein. With their five stanzas, both songs are however still among the longest to be found in farces, since most songs in farces consist of only one short stanza. The notable preference given by rhetoricians in their farces to short, well-integrated musical passages over longer lyrical interludes, accounts also for the absence of refreins. With their fairly massive stanzas and their recurrent stok the latter would only create inconvenient standstills or at least moments of low velocity. In addition, farces

\footnotetext{
40 On these 'monologues': Coigneau (1980-1983) vol. 2., 339-366.

41 See Hüsken (1987) 6o-61, 169-176.

42 Coigneau (2008).

43 Van der Laan (1938) 75-77; Lyna and Van Eeghem (1932) 46-47.
} 
show two other characteristics which favour the use of songs rather than of refreins. ${ }^{44}$ In their plots and performances farces focus primarily on lively, if not grotesque, presentations of physical situations, desires and confrontations. ${ }^{45}$ To this end, the singing of songs, more than the recitation of refreins, could add a specific physical component which could be combined with dancing or other bodily activities. Although rederijker farces certainly did not abstain from thematic conventionalities and formal mannerisms, they do show, more strongly than serious morality plays, a tendency to come closer to everyday life and speech. This 'realism' is served better by a character's deliberate decision to sing a song, usually in circumstances similar to those in sixteenth-century real life, ${ }^{46}$ than by characters' 'unconscious' and artificial speaking of refreins.

\section{Other Absentees}

The absence of refreins in rederijker farce demonstrates that rhetoricians made a restrained and selective use of their main lyric form in drama. Only in serious plays are refreins to be found, and not in all of these. Indeed, the application of refreins was not an automatism or a formal must, as is made clear by the plays written for theatrical contests that have come down to us. None of the first prize-winning plays in the contests that were organised in Ghent, in 1539, and in Antwerp and Rotterdam, both in 1561, had a refrein. ${ }^{47}$ In fact, only one of the 19 Ghent plays and one of the 14 spelen van zinne performed at the Antwerp Landjuweel were enriched with refreins. ${ }^{48}$ In Rotterdam the proportion is different: out of nine plays there were five with one or two refreins. ${ }^{49}$ The refrein in the Ghent play (Tienen: spelvan sinne in Gent 1539), like that in the Antwerp play (Zoutleeuw: spel van sinne in Antwerpen 1561) and four of those in the Rotterdam plays, are final refreins, prayers praising the solution to dramatized questions such as: 'What is the greatest comfort to dying man?' (Ghent 1539), 'What urges man most strongly to arts and science?' (Antwerp 1561) and 'Who, of those who

\footnotetext{
44 Coigneau (1992) 259-26o.

45 See Kramer (2009) 135-205.

46 Coigneau (2008) 194.

47 Coigneau (1994) $36-37$.

48 As for the Landjuweel this does not mean that refreins were generally absent. Thirteen refreins were recited as independent poems (see Ryckaert (2011) vol. 1, 555-556, 624626, 686-688, 69o-692, 748-751; vol. 2, 937-939, 953-955, 1012-1013, 1015-1017, 1070-1072, 1074-1076, 1134-1136, and 1138-1139), and in the margin of the festival, a non-official refreincontest was organized (Coigneau (2014) 94, 117-119, 124-129).

Appendix: 104-106, 107, 109-115.
} 
seemed to be abandoned by God, has ever received the greatest comfort?' (Rotterdam 1561). The use of final refreins in six out of these seven plays proves the strength of the 'culminating prayer-refrein' convention. Yet in Tienen the refrein praising God's mercy as the solution to the Ghent question is in fact not the 'final' one; it is followed by a further refrein, a prayer spoken by the same main character, Stervende mensche (Dying Man) in reaction to a toog showing a crucifix with a bleeding Christ. In this second prayer, Dying Man, finally acting true to his name, yields himself up to Jesus. Tienen actually has three refreins: before the two 'final' ones mentioned, Dying Man had already spoken an initial refrein. In this he professes, by way of exposition, the apostolic creed. More in accordance with the majority of initial refreins, Noordwijk: spel van sinne in Rotterdam 1561 and Haarlemse Pellicanisten: spel van sinne in Rotterdam 1561 have initial refreins expressing the problematic situation of the main character. The desperate exclamations in Noordwijk contrast sharply with its final refrein in praise of the Holy Spirit, who has been demonstrated to be the greatest comfort for the apostles at Whitsuntide. Maybe the contrast pleased the jury, for Noordwijk was awarded second prize. Finally, as well as its initial refrein Haarlemse Pellicanisten has a central refrein. It is used as a vehicle for the final argument produced by Ghenade Gods (God's Grace) to urge Man to come and find release from his troubles.

Considering that the use of refreins is optional, five plays with refreins to four plays without in the Rotterdam contest is a surprisingly high proportion. Leaving aside the Ghent and Antwerp contests, the general proportion tends to the inverse of the Rotterdam result. For instance, in the great Haarlem play collection, containing 69 spelen van zinne, there are 32 plays with refreins to 37 without..$^{50}$ Looking over our general corpus, no 'laws' can be discerned that might have determined the playwrights' choice to use refreins or not. Especially in drama, facteurs (or facto(e)rs), as the playwrights were called, were free to decide which formal elements their creative minds would produce out of the 'grand storehouse of rhetoric'.51 Still, the functions and effects the authors aimed at are revealed by the refreins' respective positions as described in our foregoing survey. As we have seen, the introduction of an initial refrein foregrounds and retards the expositional phase of the play's action in order to concentrate on the situation and inner life of the main character. There is of course an initial exposition of the protagonist's problem in plays without refreins, usually in shorter monologues or in speeches that form part of a more general

$5^{\circ} \quad$ See Hummelen (1968) 58-105.

$51 \quad$ Coigneau (1994) 18, 38. 
dialogue. The exposition of the main character's initial situation within the static and relatively enclosed form of the refrein is most useful in plays with a pronounced antithetical structure. In these, the protagonist's problem is solved primarily by means of a powerful confrontation later on. On the other hand, a retarding and formal 'isolation' of the main character's initial situation is less useful in discursive plays that focus not on a sudden conversion, but on a gradual development of insight by means of analytic argumentation or progressive discussion. The same holds true for the central refrein: in discursive plays there is no need for a moment of standstill such as is brought about (for example) by refreins in banquet scenes representing the protagonist's wicked life. Nor is there a need for refreins to mark an actual turning point. Similarly, dramatizations of biblical or amorous stories may develop the narrative process without a central dramatic break. On the other hand, some plays dramatizing debates do make use of a central refrein, spoken by Christ (in a toog) or by personifications of divine mercy, as a means of introducing a final consolidating argument.

The absence of refreins in the Ghent and Antwerp contest-plays (except in the case of Tienen and Zoutleeuw) may partially be explained by the fact that most of these plays are discursive ones, dramatizing a gradual accumulation of arguments and focusing more, after a short emotional start, on argumentative content than on the subjective response of the participants. ${ }^{52}$ However, this does not explain why central refreins are not used to highlight a final argument, or why there is a general abstinence from the old but lively convention of the final hymnal refrein in the Ghent and Antwerp plays. As the refrein was indissolubly associated with religious matter, the absence of both applications can more easily be explained in the Antwerp plays. The question set at the ${ }_{1561}$ Antwerp landjuweel, on what urges man to the arts and sciences, did not necessarily require a theological solution. In fact, the question was chosen precisely to accommodate the central government's prohibition of religious discussions. ${ }^{53}$ This measure, taken specially for the prestigious landjuweel, certainly discouraged authors from working too much of theology into their plays. Still, three of them designated God's Spirit as the wellspring of Man's scientific activities. In 's-Hertogenbosch: spelvan sinne in Antwerpen 1561, the closing toog, showing the allegorical figures of God's Spirit of Wisdom, Love, and Man, is not capped by religious praise or prayer, let alone by a hymnal refrein. ${ }^{54} \mathrm{~A}$ step in this direction is taken in Antwerpens Olijftack: spel van sinne in Antwerpen 1561. After a central toog involving, among other figures, the Holy Spirit, Man says

52 Coigneau (2005) 247-248.

53 Van Autenboer (1981) 48-56.

54 Ryckaert (2011) vol. 1, 473-474. 
a short prayer of seven lines. Man's final celebratory speech is, however, much longer: this is a rederijker poem glorifying rhetoric and music as gifts of the wisdom of the Holy Spirit. ${ }^{55}$ The poem comprises four stanzas of 15 lines each, the last one, like a refrein, addressing the arts as Princersse. The poem has no stok, and so the spectators were denied a true refrein as finale. In abstaining from this form, the author clearly showed his respect for the traditional and close bond between the final refrein and true prayer. This bond is affirmed in a positive way in Zoutleeuw. In this play, the final refrein recited by Man is a prayer and a laudatory contemplation, celebrating his conversion from idleness to artistic activity and his entrance into the 'palace of the arts' with the sole help of God's Spirit. ${ }^{56}$

Unlike the Antwerp landjuweel in 1561, the Ghent contest in 1539, with its set question on the greatest consolation for Dying Man, necessarily induced theologizing solutions. Strangely enough, only one of the 19 plays has refreins. The Ghent contest required scriptural argumentation and a multiple application of the toog-technique. ${ }^{57}$ Concentrating as they did on the theological content, and on the gradual development and theatrical illustration of the argument, the plays gave little scope for the amplification and fixation of emotional and contemplative responses in initial or central refreins. Still, the general abstinence from final refreins, which could have celebrated the comforting solutions with prayers of thanksgiving, remains a puzzle. An explanation may be offered by Tienen, the only Ghent play with refreins. The unusual application of two final refreins in this play seems to indicate the author found a creative way out of the situation his fellow-rhetoricians prompted to avoid the use of the 'normal' device of one final refrein. In Tienen, as we have seen, the traditional final refrein spoken by Man, celebrating the play's consoling solution, is followed by a refrein spoken by the same character, but this time as the prayer of a dying man. There are ten other Ghent plays in which the protagonist dies onstage. ${ }^{58}$ Even though these deaths are not dreadful or tragic like those in amorous plays, rhetoricians appear to have found them incompatible with final refreins. Since the latter were traditionally rather triumphant speeches by characters that are alive and well, we can indeed understand and appreciate the authors' sensitivity. So, after all, the specific, singular applications ánd the general absence of the final refrein in the Ghent and Antwerp plays may indicate that the old convention was still vigorous and reckoned with.

55 Ryckaert (2011) vol. 1, 352, l. 444-45o, and 36o-362, l. 593-652.

56 Appendix: 107 .

57 Erné and Van Dis (1982) vol. 1, 33.

$5^{8}$ Erné and Van Dis (1982) vol. 1, 15 . 
Although the refrein was their most popular as well as their most highly regarded poetical form, in their theatrical productions rhetoricians made selective use of it. The form was not 'vulgarized' by being introduced into farces, but rather reserved for serious purposes in morality plays, the genre that ranked highest in the rederijker hierarchy. In these plays the optional use of refreins appears to have been a very functional means of enriching the action's moral and dramatic appeal.

\section{Appendix}

In the following survey of refreins as they appear in plays, the latter are arranged in order of their presentation in W.M.H. Hummelen. Repertorium van het rederijkersdrama 1500-ca. 1620. Assen (1968). Their short titles and signatures, the latter in brackets, are likewise taken from Hummelen's Repertorium and its supplement (H. van Dijk, W. Hummelen, W. Hüsken, and E. Strietman. A survey of Dutch drama before the renaissance. Dutch Crossing 22 (1984) 97-131). The refreins can be identified by means of the pagination and the numbering of lines (the latter preceded by 'l.') in the editions named. Finally, the number of the characters that are involved in the presentation of the refrein is given in brackets, followed by an indication of the 'functional' position of the refrein (initial, central or final). This collection is fairly representative, but not exhaustive. Early seventeenth-century contests and plays have not been included.

1. Quiconque vult salvus esse (1 B 1): Scharpé, L. (ed.) 1900-1902. De Rovere's spel van Quiconque vult salvus esse. Leuvensche Bijdragen 4: 192-193, 1. 865-882 (3, final).

2. Maria hoedeken (1 B 2): Muller, J.W., and Scharpé L. (ed.) 1920. Spelen van Cornelis Everaert. Leiden. 11-13, l. 161-205; Hüsken, W.N.M. (ed.) 2005. De Spelen van Cornelis Everaert. 2 vol. Hilversum. Vol. 1, 90-92, l. 166-210 (1, initial).

3. Maria hoedeken (1 B 2): Muller and Scharpé (1920) 32-33, l. 875-920; Hüsken (2005) vol. 1, 123-125, 1. 879-923 (4, final).

4. Wellecomme van den predicaren (1 B 10): Muller and Scharpé (1920) 149-151, l. 7991, 99-111, 119-131, 139-151; Hüsken (2005) vol. 1, 334-338, 1. 83-95, 107-119, 131-143, $155^{-167}$ (1, initial).

5. $\quad$ Ghewillich Labuer ende Volc van Neerrynghe (1 B 12): Muller and Scharpé (1920) 194-195, 1. 403-451; Hüsken (2005) vol. 1, 409-411, 1. 407-455 (4, final).

6. Groot Labuer ende Sober Wasdom (1 B 17): Muller and Scharpé (1920) 281-282, l. 6o2-629; Hüsken (2005) vol. 1, 558-559, l. 6o2-629 (3, final). 
7. $\quad$ De wynghaert (1 B 33): Muller and Scharpé (1920) 519, l. 739-770; Hüsken (2005) vol. 2, 967-968, 1. 737-768 (3, final).

8. Die geboorte van Vrou Margriete ( $\mathrm{1}_{\mathrm{C}}$ ): De Bock, E. 1963. Een presentspel van Colijn Cailleu. Spiegel der Letteren 6: 265-266, 1. 438-473 (3, final).

9. Sint Jans onthoofdinghe (1 D 3): Laport, P., De Muij, F., and Spies, M. (ed.) 1996. Van sintJans onthoofdinghe. Zestiende-eeuws Amstersdams rederijkersstukvan Jan Thönisz. Amsterdam. 80-82, 1. 426-477 (2, central).

10. sMenschen Sin en Verganckelijcke Schoonheit (1 D 5): Nederlands Instituut der Rijksuniversiteit te Groningen (ed.) 1967. Een esbattement van smenschen sin en verganckelijcke schoonheit. Zwolle. (Zwolse drukken en herdrukken voor de Maatschappij der Nederlandse Letterkunde te Leiden 57). 147-156, l. 552-569, 592-6o9, 635-652, 681-689 (2, central).

11. Naaman (1 D 8): Hummelen, W.M.H., and Schmidt, C. (ed.) [1975]. Naaman Prinche van Sijrien. Een rederijkersspel uit de zestiende eeuw. Zutphen (Klassiek Letterkundig Pantheon 198). 47-50, l. 1-15, 28-40, 46-58, 72-84 (1, initial).

12. Eneas en Dido (1 D 12): Iwema, K. 1982-1983. Cornelis van Ghistele Van Eneas en Dido. Twee amoureuze spelen uit de zestiende eeuw. Jaarboek De Fonteine 19821983: 154-155, l. 1-39 (1, Prologhe).

13. Eneas en Dido (1 D 12): Iwema (1982-1983) 201-202, l. 1334-1381 (1, 'central').

14. Eneas en Dido (1 D 12): Iwema (1982-1983) 213-214, l.1696-1736 (1, central).

15. Wie voirmaels waeren de victoriöste ( $\left.1 \mathrm{D}_{15}\right)$ : Meertens P.J. 1967. Een esbatement ter ere van keizer Karel v (een Leids rederijkersspel uit 1552). Jaarboek De Fonteine 1967: 98-101, l. 563-666 (1, final).

16. Sanct Jooris ( 1 F 2): Leendertz, P. Jr [1907]. Middelnederlandsche Dramatische Poёzie. Leiden. 434-435, l. 271-294 (3, final).

17. Siecke stadt (1 I 1): Bloemendal, J. (ed.) 2009. Politieke en religieuze satire in zestiende-eeuws Amsterdam. Een Spel van zinnen van de Zieke Stad van Jacob Jacobsz. Jonck. Amersfoort. 66-69, l. 363-411 (1, initial).

18. Siecke stadt (1 I 1): Bloemendal (2009) 100-105, l. 784-851 (1, initial).

19. Siecke stadt (1 I 1): Bloemendal (2009) 152-154, l. 1522-1557 (3, final).

20. Cristenkercke (1 I 2): Brands, G.A. (ed.) 1921. Tspel van de Cristenkercke. Utrecht. 24-26, l. 545-62o (1, initial).

21. Cristenkercke (1 I 2): Brands (1921) 31-34, l. 765-848 (1, central).

22. Cristenkercke (1 I 2): Brands (1921) 75-78, l. 1716-1815 (1, central).

23. Cristenkercke (1 I 2): Brands (1921) 80-81, l. 1874-1941 (1, central).

24. De bekeeringe Pauli (1 K2): Steenbergen, G.J.(ed.) 1953. De bekeeringe Pauli.Zwolle (Zwolse drukken en herdrukken voor de Maatschappij der Nederlandse Letterkunde te Leiden 3). 57-59, l. 218-255 (1, initial).

25. De bekeeringe Pauli (1 K 2): Steenbergen (1953) 93-95, l. 742-8o4 (1, final).

26. tReyne Maecxsele (1 M 3): Scharpé, L. (ed.) 19o6. R. Lawet: Gheestelick Meyspel van 
tReyne Maecxsele ghezeyt de ziele. Leuven/Amsterdam (Leuvense Tekstuitgaven 2). 35-37, l. 700-740 (1, initial).

27. tReyne Maecxsele (1 M 3): Scharpé (1906) 43-45, l. 898-941 (1, central).

28. De helighe sacramente (1 M 4): Galama, E.G.A. 1941. Twee zestiende-eeuwse spelen van de Verlooren Zoone door Robert Lawet. Utrecht/Nijmegen. 24 (3, final).

29. Hetvader onse (1 M 5): Galama (1941) 27 (6, final).

3o. De Verlooren Zoone (van Lawet) (1 M 7): Galama (1941) 196-198, l. 921-98o (1, central).

31. Coninck Proetus Abantus (1 OA 2): Hüsken, W.N.M., Ramakers, B.A.M., and Schaars, F.A.M. (ed.) 1992-1998. Trou moet blijcken. Bronnenuitgave van de boeken der Haarlemse rederijkerskamer 'de Pellicanisten'. 8 vol. Assen/Slingenberg. Vol. 1 (Boek A) fol. 22 $2^{\mathrm{v}}-23^{\mathrm{v}}$, l. 1544-1611 (3, final).

32. Abrahams offerhande (1 OA 4): Hüsken, Ramakers, and Schaars (1992-1998) vol. 1 (Boek A), fol. $57^{\mathrm{r}}-57^{\mathrm{v}}$, 1. 799-850; Dibbets, G.R.W., and Hummelen, W.M.H. (ed.) 1993-1994. Abrahams Offerhande. Jaarboek De Fonteine 1993-1994: 112-114, 1. $509-556$ (1, central).

33. D'Evangelische maeltyt (1 OA 5): Hüsken, Ramakers, and Schaars (1992-1998) vol. 1 (Boek A), fol. $75^{\mathrm{v}}-76^{\mathrm{r}}$, l. 1003-106o (4, central).

34. De Wellustige Mensch (1 OA 6): Kruyskamp, C. (ed.) 1950. Dichten en spelen van Jan van den Berghe. Den Haag (Uitgave van de Vereeniging der Antwerpsche Bibliophielen II, 4). 142-143, l. 1105-1152; Hüsken, Ramakers, and Schaars (1992-1998)

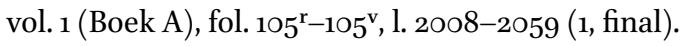

35. Sincte Paulus bekeringe (1 ов 1): Hüsken, Ramakers, and Schaars (1992-1998) vol. 2 (Boek B), fol. 12 $2^{\mathrm{v}}-13^{\mathrm{v}}$, l. 1161-1246 (1, final).

36. Paulus ende Barnabas (1 о в 4): Hüsken, Ramakers, and Schaars (1992-1998) vol. 2 (Boek B), fol. 6o ${ }^{\mathrm{r}}-6 \mathrm{o}^{\mathrm{v}}$, l. 1007-1072 (3, final).

37. Cranckheijt des Vleijsch (1 о в 7): Hüsken, Ramakers, and Schaars (1992-1998) vol. 2 (Boek B), fol. $92^{\mathrm{r}}-93^{\mathrm{r}}$, l. 462-480, 487-502, 512-526, 533-548 (1, initial).

38. Cranckheijt des Vleijsch (1 о в 7): Hüsken, Ramakers, and Schaars (1992-1998) vol. 2

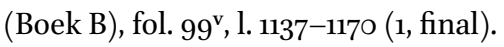

39. Verlaten Kennisse (1 ов 8): Hüsken, Ramakers, and Schaars (1992-1998) vol. 2 (Boek B), fol. $11 \mathrm{O}^{\mathrm{r}}-111^{\mathrm{r}}, 1.764-777,788-801,828-841,861-872$ (2, central).

40. Verlaten Kennisse (1 ов 8): Hüsken, Ramakers, and Schaars (1992-1998) vol. 2 (Boek B), fol. 113 ${ }^{\mathrm{v}}-114^{\mathrm{v}}$, l. 1094-1110, 1118-1135, 1143-116o, 1168-1183 (1, central).

41. Verlaten Kennisse (1 ов 8): Hüsken, Ramakers, and Schaars (1992-1998) vol. 2 (Boek B), fol. $117^{\mathrm{v}}-118^{\mathrm{r}}$, l. 1469-1527 (2, final).

42. Die propheet Jonas (1 OC 5): Hüsken, Ramakers, and Schaars (1992-1998) vol. 3 (Boek C), fol. $53^{\mathrm{v}}-54^{\mathrm{r}}, 1.588-639$ (3, central).

43. Die propheetJonas (1 OC 5):Hüsken, Ramakers, Schaars (1992-1998) vol. 3 (Boek C) fol. $55^{\mathrm{r}}-55^{\mathrm{v}}, 1.725^{-754}(1$, central $)$. 
44. Die propheet Jonas (1 OC 5): Hüsken, Ramakers, and Schaars (1992-1998) vol. 3 (Boek C), fol. $5^{6^{\mathrm{r}}-5^{6}}{ }^{\mathrm{v}}, 1.823^{-887}$ (3, central).

45. De Oude Tobijas (1 oc 7): Hüsken, Ramakers, and Schaars (1992-1998) vol. 3 (Boek C), fol. 86 $6^{\mathrm{r}}-86^{\mathrm{v}}$, l. 21-75 (1, initial).

46. De Oude Tobijas (1 oc 7): Hüsken, Ramakers, and Schaars (1992-1998) vol. 3 (Boek C), fol. 91 ${ }^{\mathrm{v}}-92^{\mathrm{r}}, 1.514-567$ (2, central).

47. De Oude Tobijas (1 oc 7): Hüsken, Ramakers, and Schaars (1992-1998) vol. 3

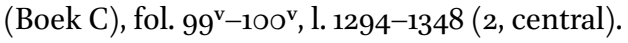

48. De Heijlige Kerck (1 OC 9): Hüsken, Ramakers, and Schaars (1992-1998) vol. 3 (Boek C), fol. $123^{\mathrm{v}}-124^{\mathrm{r}}$, l. 395-413, 423-443, 453-491 (1, initial).

49. De Heijlige Kerck (1 oc 9): Hüsken, Ramakers, and Schaars (1992-1998) vol. 3 (Boek C), fol. $127^{\mathrm{r}}-128^{\mathrm{r}}$, l. $786-875$ (1, central).

5o. De Heïlige Kerck (1 oc 9): Hüsken, Ramakers, and Schaars (1992-1998) vol. 3 (Boek C), fol. $138^{\mathrm{r}}-138^{\mathrm{v}}, 1.1811-1882$ (1, central).

51. De troost der sondaren (1 OC 10): Hüsken, Ramakers, and Schaars (1992-1998) vol.3 (Boek C), fol. $145^{\mathrm{r}}$, l. 210-247 (1, initial).

52. De troost der sondaren (1 OC 10): Hüsken, Ramakers, and Schaars (1992-1998) vol.3 (Boek C), fol. $147^{\mathrm{r}}-147^{\mathrm{v}}$, l. 453-522 (1, central).

53. De Ghichtige Mensche (1 OC 11): Hüsken, Ramakers, and Schaars (1992-1998) vol. 3 (Boek C), fol. 165 $5^{\mathrm{v}-166}$, l. 1268-1343 (Prologe).

54. Lieft boven al (1 OD 2):Hüsken, Ramakers, and Schaars (1992-1998) vol. 4 (Boek D), fol. $49^{\mathrm{r}}-49^{\mathrm{v}}$, l. 886-952 (5, final).

55. Menich Bedruct Hart aen een droege chijsterne verleijt (1 OD 9): Hüsken, Ramakers, and Schaars (1992-1998) vol. 4 (Boek D), fol. 149 ${ }^{\mathrm{r}}-149^{\mathrm{v}}$, l. 1419-1478 (2, final).

56. Josep ende Maria (1 OE 1): Hüsken, Ramakers, and Schaars (1992-1998) vol. 5 (Boek E), fol. $8^{\mathrm{v}}-9^{\mathrm{r}}$, l. $718-770$ (4, central).

57. Het lichamelijcke huis (1 OE 3): Hüsken, Ramakers, and Schaars (1992-1998) vol. 5 (Boek E), fol. 22 ${ }^{\mathrm{r}}$, l. 59-91 (1, initial).

58. Het lichamelijcke huis (1 OE 3): Hüsken, Ramakers, and Schaars (1992-1998) vol. 5 (Boek E), fol. $22^{\mathrm{v}}-23^{\mathrm{r}}$, l. 140-176 (2, initial).

59. Het lichamelijcke huis (1 OE 3): Hüsken, Ramakers, and Schaars (1992-1998) vol. 5 (Boek E), fol. $23^{\mathrm{r}}-23^{\mathrm{v}}$, l. 177-217 (4, initial).

6o. De Desolate Mensch (1 OE 5): Hüsken, Ramakers, and Schaars (1992-1998) vol. 5 (Boek E), fol. $43^{\mathrm{r}}-44^{\mathrm{v}}, 1.14-38,5^{1-76}, 95^{-119}, 142-167$ (1, initial).

61. De Desolate Mensch (1 OE 5): Hüsken, Ramakers, and Schaars (1992-1998) vol. 5 (Boek E), fol. 48 $8^{\mathrm{r}}-49^{\mathrm{v}}, 1.529-639$ (4, central).

62. Die heijlige kerck tegen heresije (1 OE 6): Hüsken, Ramakers, and Schaars (19921998) vol. 5 (Boek E), fol. $54^{\mathrm{r}}-54^{\mathrm{v}}$, 1. 120-135, 148-166, 173-188 (3, initial).

63. Die heijlige kerck tegen heresije ( 1 OE 6): Hüsken, Ramakers, and Schaars (1992-

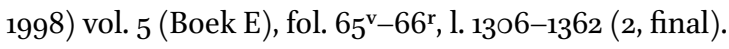


64. Veel Volks begeert Vrede (1 OE 7): Hüsken, Ramakers, and Schaars (1992-1998) vol. 5 (Boek E), fol. $75^{\mathrm{r}}-75^{\mathrm{v}}$, l. 691-759 (2, central).

65. Veel Volks begeert Vrede (1 OE 7): Hüsken, Ramakers, and Schaars (1992-1998) vol. 5 (Boek E), fol. $78^{\mathrm{v}}-79^{\mathrm{r}}$, l. 1043-1111 (2, central).

66. Meestal die om Paijs roepen (1 OE 12): Hüsken, Ramakers, and Schaars (1992-1998) vol. 5 (Boek E), fol. 140 ${ }^{\mathrm{r}}-14 \mathrm{O}^{\mathrm{v}}$, l. 15-78 (1, initial).

67. Meestal die om Paijs roepen (1 OE 12): Hüsken, Ramakers, and Schaars (1992-1998) vol. 5 (Boek E), fol. 142 $2^{\mathrm{v}}-143^{\mathrm{v}}$, l. 292-36o (1, central).

68. Meestal die om Paijs roepen (1 OE 12): Hüsken, Ramakers, and Schaars (1992-1998) vol. 5 (Boek E), fol. 151 $1^{\mathrm{v}}-15^{2}$, l. 1204-1264 (1, final).

69. Mennich Eenvoudich Mensch soect lijefdebewijs (1 OE 13): Hüsken, Ramakers, and Schaars (1992-1998) vol. 5 (Boek E), fol. $155^{\mathrm{r}}-155^{\mathrm{v}}$, l. 6-76 (1, initial).

70. Mennich Eenvoudich Mensch soect lijefdebewijs (1 OE 13): Hüsken, Ramakers, and Schaars (1992-1998) vol. 5 (Boek E), fol. 166 $166^{\mathrm{r}}$-16 , l. 1095-1170 (2, final).

71. Die daet der tirannen (1 OE 14): Hüsken, Ramakers, and Schaars (1992-1998) vol. 5

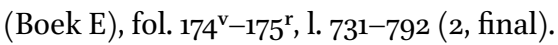

72. De andere Meij (1 OE 15): Hüsken, Ramakers, and Schaars (1992-1998) vol. 5 (Boek

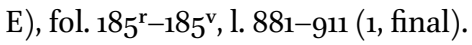

73. Het Cooren (1 of 1): Kalff, G. (ed.) 1889. Trou Moet Blycken. Tooneelstukken der zestiende eeuw. Groningen. 224-226, 1. 91-150; Hummelen, W.M.H., and Dibbets, G.R.W. (ed.) 1985. Een spel van sinnen beroerende Het Cooren (1565) van Lauris Jansz., factorvan de Haarlemse rederijkerskamer De Wijngaertrancken. Zutphen (Klassiek Letterkundig Pantheon 225). 39-41, 1. 91-150; Hüsken, Ramakers, and Schaars (1992-1998) vol. 6 (Boek F), fol. $1^{\mathrm{r}}-\mathbf{1}^{\mathrm{v}}$, l. 6-68 (1, initial).

74. Het Cooren (1 of 1): Kalff (1889) 257-258, l. 1101-1144; Hummelen and Dibbets (1985) 89-91, l. 1101-1144; Hüsken, Ramakers, and Schaars (1992-1998) vol. 6 (Boek F), fol. $16^{\mathrm{r}}-16^{\mathrm{v}}$, l. 1326-1376 (2, final).

75. De Meij (van Adriaenz.) (1 of 4): Hüsken, Ramakers, and Schaars (1992-1998) vol. 6 (Boek F), fol. 6o ${ }^{\mathrm{r}}-61^{\mathrm{r}}$, l. 776-789, 803-816, 829-841, 854-867 (1, final).

76. De Meij (van Adriaenz.) (1 of 4): Hüsken, Ramakers, and Schaars (1992-1998) vol. 6 (Boek F), fol. 6o ${ }^{\mathrm{r}}-61^{\mathrm{v}}$, l. 79o-8o2, 817-828, 842-853, 868-881 (1, final).

77. tHuis van idelheijt (1 of 5): Hüsken, Ramakers, and Schaars (1992-1998) vol. 6

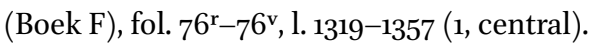

78. dEenvoudige Mensch en Schijn van Deuchden (1 of 7): Hüsken, Ramakers, and Schaars (1992-1998) vol. 6 (Boek F), fol. 93 ${ }^{\mathrm{r}}-93^{\mathrm{v}}$, l. 30-87 (1, initial).

79. Afval vant gotsalige weesen (1 OF 8): Hüsken, Ramakers, and Schaars (1992-1998) vol. 6 (Boek F), fol. $125^{\mathrm{r}}-125^{\mathrm{v}}$, l. 1209-1270 (3, final).

8o. tGeslacht der Menschen (1 of 9): Hüsken, Ramakers, and Schaars (1992-1998) vol. 6 (Boek F), fol. $127^{\mathrm{r}}-127^{\mathrm{v}}$, l. 15-6o (1, initial).

81. tGeslacht der Menschen (1 of 9): Hüsken, Ramakers, and Schaars (1992-1998) vol. 6 (Boek F), fol. 141 v-142 v , l. 1153-1211 (2, final). 
82. Mennich Goet Hart verlangt nae die Waerheijt (1 OF 10): Hüsken, Ramakers, and Schaars (1992-1998) vol. 6 (Boek F), fol. 144 ${ }^{\mathrm{r}}-144^{\mathrm{v}}, \mathrm{l}$. 19-75 (1, initial).

83. Mennich Goet Hart verlangt nae die Waerheijt (1 OF 10): Hüsken, Ramakers, and Schaars (1992-1998) vol. 6 (Boek F), fol. 16o ${ }^{\mathrm{v}}-161^{\mathrm{v}}$, l. 1341-1399 (2, final).

84. Die Ghenaede Goodts (1 OF 11): Hüsken, Ramakers, and Schaars (1992-1998) vol. 6

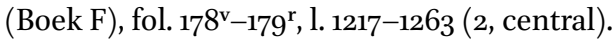

85. Die Ghenaede Goodts (1 OF 11): Hüsken, Ramakers, and Schaars (1992-1998) vol. 6 (Boek F), fol. $182^{\mathrm{r}}-182^{\mathrm{v}}$, l. 1474-1522 (4, final).

86. dEen en dAnder: verliefdheid bespot (1 or 8): Hüsken, Ramakers, and Schaars (1992-1998) vol. 8 (Boek I), fol. $75^{\mathrm{r}}-8 \mathrm{o}^{\mathrm{r}}$, 1. 20-36, 86-101, 152-168, 220-236 (1, initial).

87. dEen en dAnder: verliefdheid bespot (1 or 8): Hüsken, Ramakers, and Schaars (1992-1998) vol. 8 (Boek I), fol. 76 $6^{\mathrm{r}}-8 \mathrm{o}^{\mathrm{v}}, \mathrm{l}$. 53-68, 119-134, 184-202, 253-269 (1, central).

88. Vruechde en Vreetsaemichghe Liefde (1 ON 1): Hüsken, Ramakers, and Schaars (1992-1998) vol. 8 (Boek N), fol. 16 $6^{\mathrm{r}}-17^{\mathrm{r}}$, l. 1062-1118 (1, central).

89. De treves (1 OR 1): Hüsken, Ramakers, and Schaars (1992-1998) vol. 8 (Boek R), fol. $64^{\mathrm{r}}-64^{\mathrm{v}}, \mathrm{l} .89-143$ (1, initial).

9o. Susanna ( $\mathrm{S}_{3}$ ): Strietman, E., and Happé, P. (ed.) 2006. For Pleasure and Profit. Six Dutch rhetoricians plays with facing-page translation. Volume I: Three Biblical Plays. Lancaster University. 146-149, 1. 334-376 (1, initial).

91. Susanna ( $1 S_{3}$ ): Strietman and Happé (2006) 182-185, l. 894-929 (4, final).

92. De Ontrouwe Rentmeester ( $1 \mathrm{~S}_{5}$ ): Van den Daele, O., and Van Veerdeghem, Fr. (ed.) 1899. De Roode Roos. Zinnespelen en andere tooneelstukken der zestiende eeuw. Bergen. 178-179, l. 1419-1457 (1, central).

93. Die Trauwe (1S 6): Van den Daele and Van Veerdeghem (1899) 232-233 (4, central).

94. Judith (1 S 7): Claes, L. (ed.) 1957-1958. Tspel van Judith. Licentiaatsverhandeling Universiteit Gent. 61-63, l. 1133-1176 (2, central).

95. Judith (1 S 7): Claes (1957-1958) 73-75, l.1362-1413 (1, final).

96. Joseph (1 U 11): Dibbets, G.R.W., and Hummelen, W.M.H. (ed.) 1973-1974. Joseph, een historiaalspel van Jeronimus van der Voort (?). Jaarboek De Fonteine 19731974: 98-101, l. 387-402, 420-435, 444-459, 477-483 (1, central).

97. Joseph (1 U 11): Dibbets and Hummelen (1973-1974) 154-155, 1. 2003-2046 (1, final). 98. Joseph (1 U 11): Dibbets and Hummelen (1973-1974) 159-161, l. 2166-2221 (2, final). 99. Sint Trudo (2 o3): Kalff (1889) [see o73] 175-177, l. 2467-2513 (6, central).

10o. Vreese des Heeren en Wijsheijt (2 22): Van Vinckenroye, F. 1968. Goetwillich Herte. Een spel van sinne. Tekstuitgave met inleiding en verklarende aantekeningen. Verslagen en Mededelingen van de Koninklijke Vlaamse Academie voor Taal- en Letterkunde 1968: 376-378, 1. 314-381 (1, central).

101. De sacramente vander Nyeuwervaert (2 28): Asselbergs, W.J.M.A., and Huysmans, 
A.P. (ed.) 1955. Het spel vanden heilighen sacramentevander Nyeuwervaert. Zwolle (Zwolse drukken en herdrukken voor de Maatschappij der Nederlandse Letterkunde te Leiden 14). 183-184, l. 982-1012 (3, final).

102. dWerck der apostolen cap. 3,4 en 5 (3 A 1): Cramer, S., and Pijper, F. (ed.) 1903. Bibliotheca Reformatoria Neerlandica. Geschriften uit den tijd der hervorming in de Nederlanden. Den Haag. Vol. 1. 363-365 (3, final).

103. Den boom der schriftueren (3 A 3): Schotel, G.D.J. (ed.) 187o. Den Boom der Schriftueren van VI personagien, ghespeelt tot Middelburch in Zeelant, den eersten augusto in t jaer 1539. Utrecht. 10-11 (1, initial).

104. Tienen: spel van sinne in Gent 1539 (3 B 10): Erné, B.H., and Van Dis, L.M. (ed.) 1982. De Gentse Spelen van 1539. 2 vol. 's-Gravenhage. Vol. 2. 353-355, l. 218-261 (1, initial).

105. Tienen: spel van sinne in Gent 1539 (3 B 10): Erné and Van Dis (1982) vol. 2. 36o-362, 1. 386-441 (1, final).

106. Tienen: spel van sinne in Gent 1539 (3 B 10): Erné and Van Dis (1982) vol. 2.363-366, 1. 471-481, 487-497, 503-513, 519-529 (1, final).

107. Zoutleeuw: spel van sinne in Antwerpen 1561 (3 C 16): Kruyskamp, C. (ed.) 1962. Het Antwerpse landjuweel van 1561. Een keuze uit de vertoonde stukken (Klassieke Galerij 146). Antwerpen. 47-49, l. 669-716; Ryckaert, R. (ed) 2011. De Antwerpse spelen van 1561 naar de editie Silvius (Antwerpen 1562) uitgegeven met inleiding, annotaties en registers. Gent (Koninklijke Academie voor Nederlandse Taal- en Letterkunde: Literaire tekstedities en bibliografieën 19). Vol. 1. 661-663, l.670-717 (1, final).

108. Berchem: factie in 't Antwerps Haechspel ${ }_{15} 61$ ( 3 C 48): Ryckaert (2011) vol. 2. 13481350, 1. 88-95, 102-109, 116-123, 130-137 (1, final).

109. Noordwijk: spel van sinne in Rotterdam 1561 (3 D 1): Hollaar, H.J. (ed.) 2006. Spelen van Sinne vol schoone allegatien. Drijderley Refereynen (De Rotterdamse spelen van 1561). Delft. 197-198, 1. 494-561 (1, initial).

110. Noordwijk: spel van sinne in Rotterdam 1561 (3 D 1): Hollaar (2006) 209-210, l. 9821041 (3, final).

111. Gouda: spel van sinne in Rotterdam 1561 (3 D 2): Hollaar (2006) 96-98, l. 757-8o8 (3, final).

112. Haarlemse Wyngaertrancken: spel van sinne in Rotterdam 1561 (3 D 4): Hollaar (2006) 128-130, l. 9o9-967 (3, final).

113. Haarlemse Pellicanisten: spel van sinne in Rotterdam 1567 (3 D 5): Hollaar (2006) 133-135, l. 1-66 (1, initial).

114. Haarlemse Pellicanisten: spel van sinne in Rotterdam 1567 (3 D 5): Hollaar (2006) 158-159, 1. 869-928 (1, central).

115. Delft: spel van sinne in Rotterdam 1561 (3 D 7): Hollaar (2006) 72-73, l. 711-758 (3, final). 
116. Wercken der bermherticheyd I (3 G 1): Zeven Spelen van die Wercken der Bermherticheyd. In rijm ghemaeckt en nu tot Aemstelredam opentlijck ghespeelt Anno 1591. Amsterdam (1591) fol. B $6^{\mathrm{r}}-\mathrm{B} 7^{\mathrm{r}}(1$, central).

11 7. Wercken der bermherticheyd $I$ ( $3 \mathrm{G}_{1}$ ): Zeven Spelen (1591) fol. $\mathrm{C}_{5}^{\mathrm{v}}-\mathrm{C}^{\mathrm{v}}$ (4, final). 118. Wercken der bermherticheyd II ( $3 \mathrm{G} 2$ ): Zeven Spelen (1591) fol. E $7^{\mathrm{v}}-\mathrm{E} 8^{\mathrm{v}}$ (4, final). 119. Wercken der bermherticheyd III $\left(3_{3} \mathrm{G}_{3}\right)$ : Zeven Spelen (1591) fol. $\mathrm{G} 8^{\mathrm{r}}-\mathrm{H}_{1}{ }^{\mathrm{r}}(4$, final). 120. Wercken der bermherticheyd IV (3 G 4): Zeven Spelen (1591) fol. I $2^{\mathrm{v}}-\mathrm{I} 4^{\mathrm{v}}(2$, central).

121. Wercken der bermherticheyd $V\left({ }_{3} \mathrm{G}_{5}\right)$ : Zeven Spelen (1591) fol. $\mathrm{M}_{7}^{\mathrm{v}-\mathrm{N}_{1} \mathrm{r}}$ (4, final).

122. Wercken der bermherticheyd VI (3 G 6): Zeven Spelen (1591) fol. $\mathrm{P} 2^{\mathrm{r}}-\mathrm{P} 3^{\mathrm{r}}$; Hummelen and Schmidt ([1975]) [see 11] 40-42 (1, initial).

123. Wercken der bermherticheyd VI (3 G 6): Zeven Spelen (1591) fol. $\mathrm{Q} 3^{\mathrm{v}}-\mathrm{Q} 5^{\mathrm{r}}$ (6, final).

124. Wercken der bermherticheyd VII (3 G 7): Zeven Spelen (1591) fol. R $2^{\mathrm{v}}-\mathrm{R} 3^{\mathrm{v}}$ (1: Claghende Conscientie, initial).

125. Wercken der bermherticheyd VII ( $\left.3 \mathrm{G}_{7}\right)$ : Zeven Spelen (1591) fol. $\mathrm{R} 2^{\mathrm{v}}-\mathrm{R} 3^{\mathrm{v}}$ (1: Slave der Wet, initial).

126. Wercken der bermherticheyd VII ( $\left.{ }_{3} G_{7}\right)$ : Zeven Spelen (1591) fol. S $4^{\mathrm{v}}-\mathrm{S} 6^{\mathrm{r}}(6$, central).

127. Elckerlijc (4 04): Van Elslander, A. (ed.) 1985. Den spieghel der salicheyt van Elckerlijc. Eigth ed. Antwerpen. (Klassieke Galerij 61). 33-34, l. 535-563; Wilmink, W., and Ramakers, B.A.M. (ed.) 1998. Mariken van Nieumeghen \& Elckerlijc. Zonde, hoop en verlossing in de late Middeleeuwen. Amsterdam. 194, 1. 535-563 (1, central).

128. Pyramus ende Thisbe (4 05): Van Es, G.A. (ed.) 1965. Piramus en Thisbe. Twee rederijkersspelen uit de zestiende eeuw. Zwolle (Zwolse drukken en herdrukken voor de Maatschappij der Nederlandse Letterkunde te Leiden 50). 224-226, 1. 837-888 (1, central).

129. De spiegel der minnen (4 o7): Immink, M.W. (ed.) 1913. De Spiegel der minnen door Colijn van Rijssele. Utrecht (Utrechtsche bijdragen voor Letterkunde en Geschiedenis VIII). 79-80, l. 2234-2278 (1, initial).

130. De spiegel der minnen (4 O7): Immink (1913) 84-85, l. 2384-2435 (1, initial).

131. De Evangelische Leeraer (4 o9): De Bruin, C.C. (ed.) 1989-199o. Een seer schoon Spel van zinnen ghemaeckt by mijn Heer Johan Wtenhove. Jaarboek De Fonteine 1989-199o: 42-44, l. 337-375 (1, central).

132. De wortel van retoorijka (2 34): Van Boheemen, F.C., and Van der Heijden, Th.C.J. 1985. De Westlandse rederijkerskamers in $d e{ }_{1} 6^{e}$ en $17^{e}$ eeuw. Met een tekstuitgave, inleiding en aantekeningen van het Spelvan Sinne 'De Wortel van Rethoorijka.' Amsterdam. 120-122, l. 179-218 (1, initial).

133. De wortelvan retoorijka (2 34):Van Boheemen and Van der Heijden (1985) 127-129, 1. 279-330 (1, initial). 
134. De wortel van retoorijka (2 34): Van Boheemen and Van der Heijden (1985) 164166, l. $95^{2-988}$ (4, final).

\section{Bibliography}

Asselbergs, W.J.M.A., and A.P. Huysmans (ed.) 1955. Het spel vanden heilighen sacramente vander Nyeuwervaert. Zwolle (Zwolse drukken en herdrukken voor de Maatschappij der Nederlandse Letterkunde te Leiden 14).

Van Autenboer, E. 1981. Het Brabants landjuweel der rederijkers (1515-1561). Middelburg (Leuvense studiën en tekstuitgaven Nieuwe Reeks, 2).

Beckerman, B. 1970. Dynamics of Drama. Theory and Method of Analysis. New York.

Bloemendal, J. (ed.) 2009. Politieke en religieuze satire in zestiende-eeuws Amsterdam. Een Spel van zinnen van de Zieke Stad van Jacob Jacobsz. Jonck. Amersfoort.

De Bock, E. 1963. Een presentspel van Colijn Cailleu. Spiegel der Letteren 6: 241-269.

Van Boheemen, F.C., and Th.C.J. van der Heijden. 1985. De Westlandse rederijkerskamers in de ${ }_{1} 6^{e}$ en $17^{e}$ eeuw. Met een tekstuitgave, inleiding en aantekeningen van het Spel van Sinne 'De Wortel van Rethoorijka'. Amsterdam.

Van Boheemen, F.C., and Th.C.J. van der Heijden. 1999. Retoricaal Memoriaal. Bronnen voor de geschiedenis van de Hollandse rederijkerskamers van de middeleeuwen tot het begin van de achttiende eeuw. Delft.

Brands, G.A. (ed.) 1921. Tspel van de Cristenkercke. Utrecht.

Van Bruaene, A.-L. 2008. Om beters wille. Rederijkerskamers en de stedelijke cultuur in de Zuidelijke Nederlanden (1400-1650). Amsterdam.

De Bruin, C.C. (ed.) 1989-199o. Een seer schoon Spel van zinnen ghemaeckt by mijn Heer Johan Wtenhove. Jaarboek De Fonteine 1989-199o: 21-94.

De Castelein, M. 1555. De Const van Rhetoriken. Gent (Reprint 1986: Oudenaarde).

Claes, L. (ed.) 1957-1958. Tspel van Judith. Licentiaatsverhandeling Gent University.

Coigneau, D. 1980-1983. Refreinen in het zotte bij de rederijkers. 3 vol. Gent (Koninklijke Academie voor Nederlandse Taal- en Letterkunde vi, 111).

Coigneau, D. 1992. Een vreughdich liedt moet ick vermanen. Positie en gebruikswijzen van het rederijkerslied. In Een zoet akkoord. Middeleeuwse lyriek in de Lage Landen, ed. F. Willaert e.a. Amsterdam: $255^{-267}$.

Coigneau, D. 1994. Strofische vormen in het rederijkerstoneel. In Spel in de verte. Tekst, structuur en opvoedingspraktijkvan het rederijkerstoneel, ed. B.A.M. Ramakers. Gent (Jaarboek De Fonteine 1991-1992): 17-44.

Coigneau, D. 1995. De Const van Rhetoriken, Drama and Delivery. In Rhetoric-Rhétoriqueurs-Rederijkers, ed. J. Koopmans, M.A. Meadow, K. Meerhoff, and M. Spies. Amsterdam (Koninklijke Nederlandse Akademie van Wetenschappen Verhandelingen, Afd. Letterkunde, Nieuwe Reeks, vol. 162): 123-140. 
Coigneau, D. 20oo. Bedongen creativiteit. Over retoricale productieregeling. In Medioneerlandistiek. Een inleiding tot de Middelnederlandse letterkunde, ed. R. JansenSieben, J. Jansens and F. Willaert. Hilversum (Middelnederlandse Studies en Bronnen LXIX): 129-137.

Coigneau, D. 2003. Les concours de 'referain'. Une introduction à la rhétorique Néerlandaise. In Première poésie Française de la Renaissance. Autour des Puys poétiques normands, ed. J.-C. Arnould and T. Mantovani. Paris (Colloques, congrès et conférences sur la Renaissance. Collection dirigée par Claude Blum 33): 489-503.

Coigneau, D. 2005. Emotions and Rhetoric in rederijker Drama. In Emotions in the Heart of the City (14th-16th century), ed. E. Lecuppre-Desjardin and A.-L. Van Bruaene. Turnhout (Studies in European Urban History (110o-18oo), vol. 5): 243-256.

Coigneau, D. 2008. 'Vrient, ghij moet eens singen'. Het lied in de rederijkersklucht. In De fiere nachtegaal. Het Nederlandse lied in de middeleeuwen, ed. L.P. Grijp and F. Willaert. Amsterdam: 191-204.

Coigneau, D. 2014. 'Verbeyt den Tijt' en de bijdragen van De Olijftak aan het Antwerpse landjuweel (1561). In Menich Constich Gheest. Het Antwerpse landjuweel van ${ }_{1561}$ anders bekeken, ed. J. Vandommele and R. Ryckaert. Gent (Jaarboek De Fonteine 2011-2012): 85-156.

Cramer, S., and F. Pijper (ed.) 1903-1914. Bibliotheca Reformatoria Neerlandica. Geschriften uit den tijd der hervorming in de Nederlanden. 10 vol. Den Haag.

Van den Daele, O., and F. van Veerdeghem (ed.) 1899. De Roode Roos. Zinnespelen en andere tooneelstukken der zestiende eeuw. Bergen.

Debaene, L. 1951. De Nederlandse volksboeken. Ontstaan en geschiedenis van de Nederlandse prozaromans, gedrukt tussen 1475 en 1540 . Antwerpen.

Dibbets, G.R.W., and W.M.H. Hummelen (ed.) 1973-1974. Joseph, een historiaalspel van Jeronimus van der Voort (?). Jaarboek De Fonteine 1973-1974: 43-166.

Dibbets, G.R.W., and W.M.H. Hummelen (ed.) 1993-1994. Abrahams Offerhande. Jaarboek De Fonteine 1993-1994: 9-148.

Van Dijk, H., W. Hummelen, W. Hüsken, and E. Strietman. 1984. A survey of Dutch drama before the renaissance. Dutch Crossing 22: 97-131.

Van Dixhoorn, A. 2008. Chambers of Rhetoric: Performative Culture and Literary Sociability in the Early Modern Northern Netherlands. In The Reach of the Republic of Letters. Literary and Learned Societies in Late Medieval and Early Modern Europe, ed. A. van Dixhoorn and S. Speakman Sutch, vol. 1. Leiden, Boston (Brill's Studies in Intellectual History 168): 119-157.

Van Dixhoorn, A. 2009. Lustige geesten. Rederijkers in de Noordelijke Nederlanden (14801650). Amsterdam.

Van Elslander, A. 1953. Het refrein in de Nederlanden tot 1600. Gent (Koninklijke Vlaamse Academie voor Taal- en Letterkunde VI, 71).

Van Elslander, A. (ed.) 1985. Den spyeghel der salicheyt van Elckerlijc. Eigth ed. Antwerpen (Klassieke Galerij 61). 
Erné, B.H., and L.M. van Dis (ed.) 1982. De Gentse Spelen van 1539. 2 vol. 's-Gravenhage. Van Es, G.A. 1965. Piramus en Thisbe. Twee rederijkersspelen uit de zestiende eeuw. Zwolle (Zwolse drukken en herdrukken voor de Maatschappij der Nederlandse Letterkunde te Leiden $\left.5^{\circ}\right)$.

Galama, E.G.A. 1941. Twee zestiende-eeuwse spelen van de Verlooren Zoone door Robert Lawet. Utrecht/Nijmegen.

Van der Heijden, Th.C.J., and F.C. van Boheemen 1999. Met Minnen Versaemt. De Hollandse rederijkers vanaf de middeleeuwen tot het begin van de achttiende eeuw. Delft (Bronnen en bronnenstudies).

Hollaar, H.J. (ed.) 2006. Spelen van Sinne vol schoone allegatien. Drijderley Refereynen (De Rotterdamse spelen van 1561). Delft.

Hummelen, W.M.H. 1958. De sinnekens in het rederijkersdrama. Groningen.

Hummelen, W.M.H. 1968. Repertorium van het rederijkersdrama 1500-ca. 1620. Assen.

Hummelen, W.M.H. 1984. The Dramatic Structure of the Dutch Morality. Dutch Crossing 22: 17-26.

Hummelen, W.M.H. 1992. Het tableau vivant, de 'toog', in de toneelspelen van de rederijkers. Tijdschrift voor Nederlandse taal- en letterkunde 108: 193-222.

Hummelen, W.M.H., and G.R.W. Dibbets 1985. Een spel van sinnen beroerende 'Het Cooren' (1565) van Lauris Jansz., factor van de Haarlemse rederijkerskamer De Wijngaertrancken. Zutphen (Klassiek Letterkundig Pantheon 225).

Hummelen, W.M.H., and C. Schmidt (ed.) [1975]. Naaman Prinche van Sijrien. Een rederijkersspel uit de zestiende eeuw. Zutphen (Klassiek Letterkundig Pantheon 198).

Hüsken, W.N.M. 1987. Noyt Meerder Vreucht. Compositie en structuur van het komische toneel in de Nederlanden voor de Renaissance. Deventer.

Hüsken, W.N.M. 1994. Strofische vormen in het rederijkerstoneel in historisch perspectief. In Spel in de verte. Tekst, structuur en opvoeringspraktijkvan het rederijkerstoneel, ed. B.A.M. Ramakers, Gent (Jaarboek De Fonteine 1991-1992): 45-58.

Hüsken, W.N.M. (ed.) 2005, De spelen van Cornelis Everaert. 2 vol. Hilversum.

Hüsken W.N.M., B.A.M. Ramakers, and F.A.M. Schaars (ed.) 1992-1998. Trou moet blijcken. Bronnenuitgave van de boeken der Haarlemse rederijkerskamer 'de Pellicanisten'. 8 vol. Assen.

Immink, M.W. (ed.) 1913. De Spiegel der minnen door Colijn van Rijssele. Utrecht (Utrechtsche bijdragen voor Letterkunde en Geschiedenis viII).

Iwema, K. (ed.) 1982-1983. Cornelis van Ghistele 'Van Eneas en Dido'. Twee amoureuze spelen uit de zestiende eeuw. Jaarboek De Fonteine 1982-1983: 103-244.

Kalff, G. (ed.) 1889. Trou Moet Blycken. Tooneelstukken der zestiende eeuw. Groningen.

Kramer, F. 2009. Mooi vies, knap lelijk. Grotesk realisme in rederijkerskluchten. Hilversum.

Kruyskamp, C. (ed.) 1950. Dichten en spelen van Jan van den Berghe. Den Haag (Uitgave van de Vereeniging der Antwerpsche Bibliophielen II, 4). 
Kruyskamp, C. (ed.) 1962. Het Antwerpse landjuweel van 1561. Een keuze uit de vertoonde stukken. Antwerpen (Klassieke Galerij 146).

Van der Laan, N. 1938. Uit het archief der Pellicanisten. Vier zestiende-eeuwse esbatementen. Leiden.

Laport, P., F. de Muij, and M. Spies (ed.) 1996. 'Van sint Jans onthoofdinghe'. Zestiendeeeuws Amsterdams rederijkersstuk van Jan Thönisz. Amsterdam.

Leendertz Jr., P. [1907]. Middelnederlandsche Dramatische Poëzie. Leiden.

Lyna, F., and W. van Eeghem 1932. 'De sotslach'. Klucht uit ca. 1550. Voor het eerst naar het handschrift uitgegeven. Brussel.

Mak, J.J. (ed.) 1955. De gedichten van Anthonis de Roovere. Zwolle.

Mareel, S. 2010. Voor vorst en stad. Rederijkersliteratuur en vorstenfeest in Vlaanderen en Brabant (1432-1561). Amsterdam.

Meertens, P.J. 1967. Een esbatement ter ere van keizer Karel v (een Leids rederijkersspel uit 1552). Jaarboek De Fonteine 1967: 75-105.

Muller, J.W., and L. Scharpé (ed.) 1920. Spelen van Cornelis Everaert. Leiden.

Nederlands Instituut der Rijksuniversiteit te Groningen (ed.) 1967. Een esbattement van smenschen sin en verganckelijcke schoonheit. Zwolle (Zwolse drukken en herdrukken voor de Maatschappij der Nederlandse Letterkunde te Leiden 57).

Oosterman, J.B. 1995. De gratie van het gebed. Middelnederlandse berijmde gebeden: overlevering en functie met bijzondere aandacht voor produktie en receptie in Brugge (1380-1450). 2 vol. Amsterdam.

Pikhaus, P. 1989. Het tafelspel bij de rederijkers. 2 vol. Gent (Koninklijke Academie voor Nederlandse Taal- en Letterkunde VI, 118).

Resoort, R.J. 1988. Een schoone historie vander borchgravinne van Vergi. Onderzoek naar de intentie en gebruikssfeer van een zestiende-eeuwse prozaroman. Hilversum (Middeleeuwse Studies en Bronnen IX).

Ryckaert, R. (ed.) 2011. De Antwerpse spelen van 1561 naar de editie Silvius (Antwerpen 1562) uitgegeven met inleiding, annotaties en registers. 2 vol. Gent (Koninklijke Academie voor Nederlandse Taal- en Letterkunde: Literaire tekstedities en bibliografieën, nr. 19).

Scharpé, L. (ed.) 1900-1902. De Rovere's spel van 'Quiconque vult salvus esse'. Leuvensche Bijdragen 4: 155-193.

Scharpé, L. (ed.) 19o6. R. Lawet: Gheestelick Meyspel van tReyne Maecxsele ghezeyt de ziele. Leuven, Amsterdam (Leuvense Tekstuitgaven 2).

Schotel, G.D.J. (ed.) 1870. Den Boom der Schriftueren van vi personagien, ghespeelt tot Middelburch in Zeelant, den eersten augusto in tjaer 1539. Utrecht.

Steenbergen, G.J. (ed.) 1953. De bekeeringe Pauli. Zwolle (Zwolse drukken en herdrukken voor de Maatschappij der Nederlandse Letterkunde te Leiden 3).

Strietman, E., and P. Happé (ed.) 2006. For Pleasure and Profit. Six Dutch rhetoricians plays with facing-page translation. Volume 1: Three Biblical Plays. Lancaster University. 
Vinck, P. 1976-1977. Het volksboek Die Historie van Peeter van Provencen ende die schoone Maghelone van Napels. Jaarboek De Fonteine 1976-1977, I: 3-46.

Van Vinckenroye, F. 1968. Goetwillich Herte. Een spel van sinne. Tekstuitgave met inleiding en verklarende aantekeningen. Verslagen en Mededelingen van de Koninklijke Vlaamse Academie voor Taal- en Letterkunde 1968: 352-427.

Wilmink, W. and B.A.M. Ramakers (ed.) 1998. Mariken van Nieumeghen \& Elckerlijc. Zonde, hoop en verlossing in de late Middeleeuwen. Amsterdam.

Zeven Spelen van die Wercken der Bermherticheyd. In rijm ghemaeckt en nu tot Aemstelredam opentlijck ghespeelt Anno 1591. Amsterdam 1591. 